\title{
50 Years of Membrane Techniques in Dairy Technology
}

\author{
JL Maubois* \\ INRA, Dairy Research Laboratory, France \\ Submission: March 17, 2017; Published: March 30, 2017 \\ *Corresponding author: JL Maubois, INRA, Dairy Research Laboratory, France, Email: jean-louis.maubois@wanadoo.fr
}

\section{Introduction}

Initially developed for answering to military needs: desalination of sea water for sailors or uranium isotope enrichment, membrane technologies: ultra filtration (UF), microfiltration (MF), nano filtration $(\mathrm{NF})$, reverse osmosis (RO) was then implemented in numerous industrial fields. Our research team has largely participated to insert them in many operation units of dairy technology.

In this short review, we will rapidly describe the main applications of uses of UF in cheese-making and in whey treatment, developments of MF for removing microorganisms from raw milk and for separating casein micelles. For each of the chosen examples, the requested knowledge in Dairy Science which was necessary to acquire for optimizing the application will be evocated. Finally, progress in human nutrition made feasible by membrane technologies will be also shortly reviewed.

\section{UF in dairy technology}

Use of UF was simultaneously proposed at the end of the 60's in USA for whey proteins recovery [1] and in France for cheese making [2,3]. Both applications have known large industrial developments and UF equipment is as common as cream separator in dairy plant. Increase of protein content by UF of cheese milk is used at three levels: standardization at $36 \pm 2 \mathrm{~g}$. L 1 , intermediate level $100-120 \mathrm{~g} . \mathrm{L}^{-1}$ or full concentration 180 $200 \mathrm{~g} . \mathrm{L}^{-1}$. Practically, all of the main varieties of cheese are now made by using UF all over the world. One of the main application of the MMV process was the production of "Feta" and "Domiati" cheeses. The developed process has not only allowed making feasible an old dream of cheese maker i.e. "to realize the cheese transformation in the selling package" but also to completely avoid the environmental damages caused by the highly salted whey issued during the traditional technology. If whey treatment has required relatively few increases of knowledge in dairy science that was not the case for producing satisfactory flavored cheese through UF technology (MMV process). The increase in buffering capacity (4 to 6 times increase of Ca salts content) of the "liquid pre-cheese" has made necessary i) to determine effect of that characteristic on lactic starter lysogeny acting on soft cheese ripening ii) to lower renneting $\mathrm{pH}$ (in order to solubilize colloidal Ca salts) at a value taking in consideration ionization regression of phosphoseryl groups of casein i.e. around 5.0. for Brie cheese varieties. For lactic curd cheese such as Quarg, deepen characterization of the rheological behavior of concentrated curd during ultra filtration has allowed to adjust design (membrane length and pump concept) of UF equipment for obtaining the requested cheese texture [4]. Same progresses in knowledge were also necessary for using UF in the making of cheese varieties from goat's and ewe's milk. New uses of the end product of UF of milk and whey i.e. ultra filtrate were found in animal nutrition, for improving lactose production process or even through yeast fermentation, transformation in alcohol for drinking (Carbery process) or for fuel.

\section{MF in Dairy Technology}

Industrial development of MF in dairy technology became a reality thanks to two major innovations: a ceramic multichannel with a high mechanical resistance and a new hydraulic concept (co-current recirculation in the micro filtrate part of the membrane) which maintains an uniform and low trans membrane pressure. MF membrane with a pore size diameter of $1.4 \mu \mathrm{m}$ allows the specific separation of contaminating microflora of skim milk. Average decimal reduction is closed to 3.0 or higher according to the initial total count. Such a removal of contaminating flora has led to propose to the consumers' long life raw fluid milk ( 3 weeks) in France and long life pasteurized milk (5 weeks) in Canada and many other countries including China. It has also assured hygienic safety of raw milk cheeses [5]. This last application has required from dairy microbiologists deepen studies for identifying the microorganisms: strains of lactic starters, NSLAB (non starter lactic acid bacteria), yeasts, propionic bacteria, Hafnia alvei, etc which must be present in the microbial ecosystem added to MF milk for obtaining the right flavor for each variety of cheese [4]. MF membrane with a pore 
size diameter of $0.1 \mu \mathrm{m}$ allows specific separation of micellar casein. The retentate standardized at a casein content of 32 $-35 \mathrm{~g} . \mathrm{L}^{-1}$ is now the cheese milk entering in the highly mechanized cheese plants [5]. The $0.1 \mu \mathrm{m}$ micro filtrate qualified by Maubois et al. [6] as an ideal whey is the best material for obtaining through membrane UF the WPI (Whey Protein Isolates) requested for infant food formulas and other specialized human foods. Indeed, it is sterile, it contains no residual fat and absence of $\kappa$-glycomacropeptide in these WPI increases the content in aromatic amino-acids (Try, Phe and Tyr) which are essential for the development of infants. Moreover, if MF $0.1 \mu$ mis realized at temperature around $37^{\circ} \mathrm{C}$, whey proteins are in native state i.e. with their optimal bio-active properties. Biochemical studies done on the individual whey proteins separated from these native WPI have shown the high thermal reactivity of $\beta$-lactoglobulin linking a lactose molecule as soon as above $37^{\circ} \mathrm{C}$ [7].

\section{Human Nutrition}

Thanks to the MF and UF applications summarized above, large amounts of purified milk proteins became available and have allowed numerous studies of their physiological efficiency on human beings. Bounous et al. [8] have shown the positive effect of native WPI on immune-regulation of patients suffering of diverse carcinogenetic diseases through the bio-synthesis of glutathion. Leucine ${ }^{13} \mathrm{C}$ and ${ }^{15} \mathrm{~N}$ in situ labelling of milk proteins through cow's perfusion have been obtained and then purified and given to human volunteers. The observations realized by Boirie et al. [9] with these protein sources have allowed to define the new original concept of slow (micellar casein) and fast (whey proteins) proteins. The same team has also shown that the whey proteins have the highest NPPU (Net Post Prandial Utilization) which reacheson humans $97 \%$ vs $80 \%$ for whole milk proteins. This result has originated protein foods specially dedicated for the nutrition of athletes or elderly people. Hydrolysis of WPI in a enzymatic membrane reactor in the conditions patented by Maubois et al. [10] leads to the production of a very defined peptide mixture (2 to residues) corresponding to the extremely precise characteristics (totally absorbed on $70 \mathrm{~cm}$ of small intestine) of foods for enteral re-animation. MF separation from rennetted micellar casein of $\kappa$-glycomacropeptide followed by UF concentration of this peptide tested on humans induced secretion of CCK (cholecystokinine), hormone causing contraction of gallbladder and regulation of the secretion of pancreatic enzymes and consequently improving fat digestion and regulating food intake [11].

\section{Conclusion}

Membrane technologies have originated decisive progress in dairy technology in the last 50 years for cheese making not only concerning the cheese itself but also for the co-product, the whey which is now not a by-product but a co-product with a high added value. Hygienic and safety quality of numerous dairy products has also resulted of the development of MF. These advances have been obtained thanks to a constant exchange between dairy scientists (biochemists, microbiologists, rheologists, process engineers) and dairy technologists. Both groups have through this cooperation increased their knowledge on this extraordinary liquid which is milk. Further researches are still needed in many fields such as the deep characterization of the components of microbial ecosystems leading to the optimal texture and flavor of each cheese variety or the potential applications of membrane reactors for producing either biomass or molecules having a physiological action on humans. As shortly described, milk components separated through membrane technologies have also originated significant progress in the knowledge of their bio-assimilation in human digestive tract. The research field so opened is immense particularly for determining the sophisticated mechanisms carrying out the bio-activity in $\mathrm{Ca}$ absorption (casein phosphopeptides), exorphin action ( $\beta$-casomorphin peptide), immune-protection (lactoferricin peptide), etc [12].

\section{References}

1. Fenton-May R, Hill G, Amundson CH (1971) Use of ultra filtration/ reverse osmosis systems for the concentration and fractionation of whey. J Food Sci 36: 14-20.

2. Maubois JL, Mocquot G (1971) Préparation de fromage à partir de préfromage liquide obtenu par ultrafiltration du lait. Lait 51(508): 495-533.

3. Maubois JL, Roger L, Brulé G, Piot M (1979) Hydrolysat enzymatique total des protéines de lactosérum. Obtention et applications. Brevet $\mathrm{N}$ $79(16): 483$.

4. Mistry V, Maubois JL (2004) Application of membrane technologies to cheese production in Cheese: chemistry, physics and microbiology. Volume 1, (3 ${ }^{\text {rd }}$ Edn), Elsevier, New York USA, pp. 493-522.

5. Saboya LV, Maubois JL (2000) Current developments of microfiltration technology in the dairy industry. Le Lait 80(6): 541-553.

6. Maubois JL, Fauquant J, Famelart MH, Caussin F (2001) Milk microfiltrate, a convenient starting material for fractionation of whey proteins and derivatives. The importance of whey and whey components in food and in nutrition, B Behr's Verlag.

7. Morgan F, Mollé D, Henry G, Venien A, Léonil J, et al. (1999) Glycation of bovine $\beta$-lactoglobulin: effect on the protein structure. International Journal of Food Science and Technology 34: 429-435.

8. Bounous G, Batist G, Gold P (1991) Whey proteins in cancer prevention. Cancer Lett 57(2): 91-94.

9. Boirie Y, Dangin M, Gachon P, Vasson MP, Maubois JL, et al. (1997) Slow and fast dietary proteins differently modulate postprandial protein accretion. Proc Nat Acad Sci 94(26): 14930-14935.

10. Maubois JL, Mocquot G, Vassal L (1969) Procédé de traitement du lait et de sous produits laitiers. French Patent 2 : 52-121.

11. Corring T, Levenez F, Cuber JC, Beaufrère B, Boirie Y, et al. (1997) Release of of cholecystokinin in humans after the ingestion of Glycomacropeptide. Rosemont, USA, p. 34.

12. Maubois JL, Léonil J (1989) Peptides du laità activité biologique. Le Lait 69(4): 245-269. 
This work is licensed under Creative

Commons Attribution 4.0 Licens

DOI: 10.19080/JDVS.2017.02.555576
Your next submission with Juniper Publishers will reach you the below assets

- Quality Editorial service

- Swift Peer Review

- Reprints availability

- E-prints Service

- Manuscript Podcast for convenient understanding

- Global attainment for your research

- Manuscript accessibility in different formats

( Pdf, E-pub, Full Text, Audio)

- Unceasing customer service

Track the below URL for one-step submission https://juniperpublishers.com/online-submission.php 